\title{
テーパーつき円柱の渦励振 \\ Vortex induced vibration of tapered cylinders
}

河井宏允 ${ }^{* 1}$

Hiromasa Kawai

This paper describes an experimental study of the vortex induced vibration of tapered cylinders which is being used for the tower. In the experiment, effects of turbulence, structural damping and taper were investigated. From the investigation, the following results were obtained.

1. The vortex induced vibration occurs for any types of cylinders from a straight cylinder and a full tapered cylinder when the structural damping is small enough both in smooth and turbulent boundary layer flows.

2. The tapered part does not effect so much on the vortex induced vibration when the tapered part is less than a half of the cylinder height, but the onset velocity of the vibration shifts to the higher velocity and the velocity rage of the vibration becomes wider when the tapered part is beyond $3 / 4$ of the height.

3. The response is much larger at the higher wind velocity in the turbulent flow than in the smooth flow when the tapered part is beyond $3 / 4$ of the height.

\section{1. 序}

本研究は, 最近通信用の鉄塔に使用されるように なってきたテーパー付きの独立円柱に関して, 渦励振 に及ぼすテーパーの影響, 構造減衰の影響, 流れの性 状の影響を境界層風洞実験によって検討したものであ る。実験の結果, テーパーをつけることによって渦励 振がおさまるとは限らないこと, また気流の乱れが大 きい程渦励振が小さくなるとは限らないことなどの事 実が明らかになった。また，実験したすべての場合で， 構造減衰が $1 \%$ 以上では, 渦励振はほとんど生じない ことが分かった。

\section{2. 実駼概要}

実験は東京電機大学理工学部の境界層風洞を用いて 行った。この風洞は, 全長 $19 \mathrm{~m}$, 測定部長 $10 \mathrm{~m}$, 測定 部断面 $1.2 \mathrm{~m} \times 1.2 \mathrm{~m}$ の単回路水平循環型の木製風洞 である。実験には, Fig.1 に示した, 高さ $50 \mathrm{~cm}$ の゙ル サ材製の剛模型 5 体を使用した。Fig. 1 に, 模型の有 効一般化質量と固有振動数もあわせて示した。有効一 般化質量 $\mathrm{m}^{*}$ は,

$$
m^{*}=\int_{0}^{1} m f(\xi)^{2} d \xi / \int_{0}^{1} D^{2} f(\xi) d \xi
$$

で定義され，一般化質量と一般化風力の比を表してい る。有効一般化質量は, 高さ方向に形の荤う構造物の 一般化変位を相互比較する際に極めて重要な量であり, これが同じ場合には, 模型の形が違っても空力的にみ て同じ特性を有していると考えてよい。今回の模型で

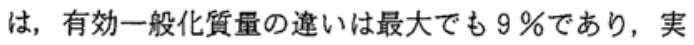
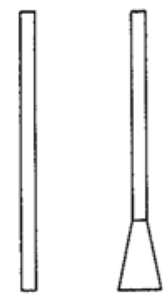

$\bigcirc$
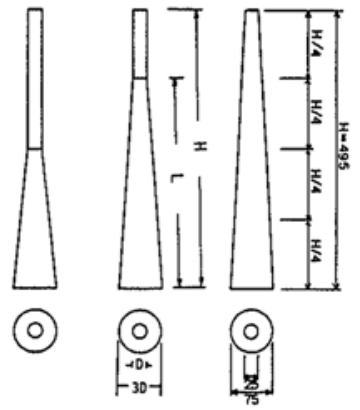

(0)

\begin{tabular}{|c|c|c|c|c|c|}
\hline $\mathrm{m}^{*}$ & 196 & 178 & 188 & 186 & 188 \\
\hline $\mathrm{n}_{0}[\mathrm{~Hz}]$ & 26.4 & 26.7 & 24.7 & 21.8 & 19.2 \\
\hline
\end{tabular}

Fig.1 Models of parallel and tapered cylinders

験結果は定量的に相互比較が可能であると考えて良い。 円柱は風方向及び風直角方向にロッキング振動する 振動天秤上に設置した。寒験時の隇衰定数は $0.2 \% \sim 2 \%$ である。実験気流は, 乱れのない一様流中及びべき指 数約 0.3 の乱流境界層流の 2 種類である。

\section{3. 実験結果}

3. 1 一様中での風直角方向振動

Fig. 2 は，一様流中における風直角方向の応答特性 がテーパーの度合いによってどのように変化するかを 調べたものである。図の縦軸は模型頂部の変動変位の

*1 東京電機大学理工学部, 教授

Professor, Tokyo Denki University, College of Science and Engineering 

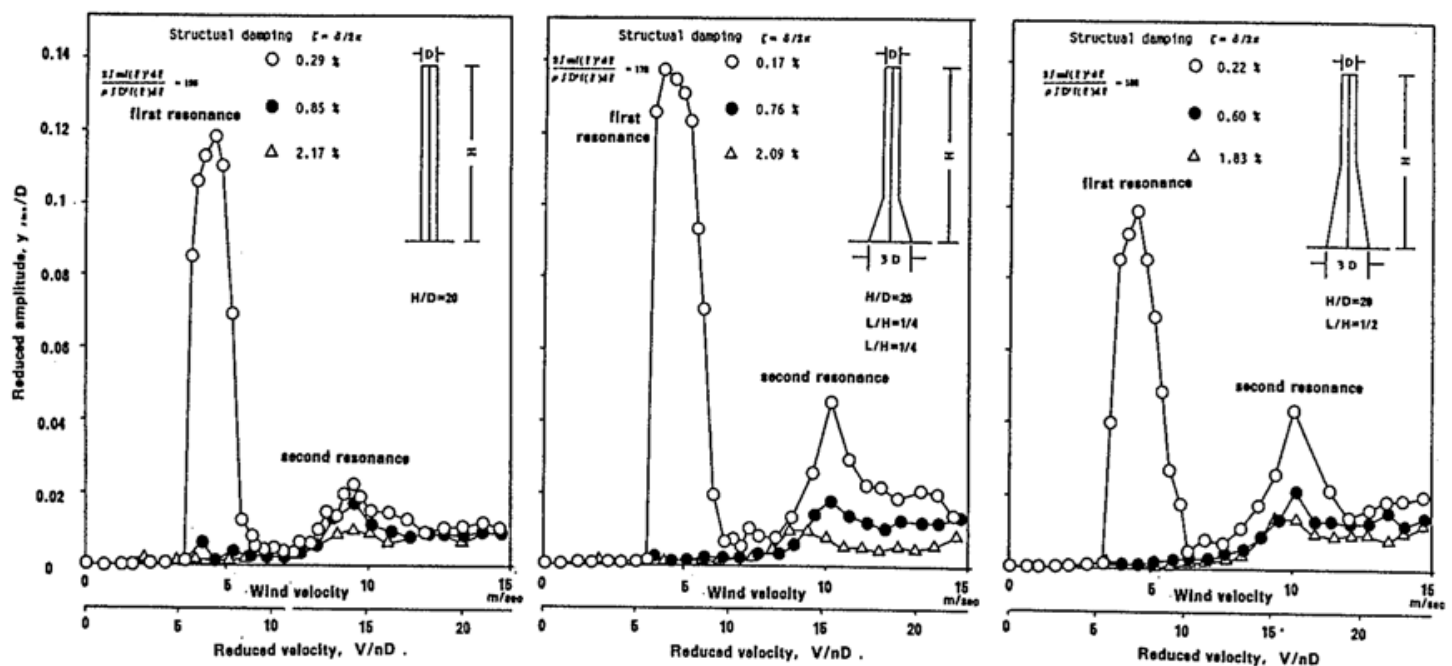

RMS 值 (標準偏差) を模型高 さで割った無次元変位（回転 角), 図の横軸は風速を模型の 固有振動数之模型頂部断面の 直径との積で割った換算風速 を示している。

隇衰定数が $0.3 \%$ 程度の場 合, Fig. 2 より分かるように, どの断面においても, 無次元 風速 5 から 10 の間の風速で 渦励振が生じ, 円柱は風直角 方向に激しく振動する。渦励 振の発振風速は, Fig. 3 に示 したように, テーパーの無い 円柱 (模型 A) から高さの半 分までテーパーがついた円柱 （模型C）までは換算風速 5

付近であるが, 底部から $3 / 4$
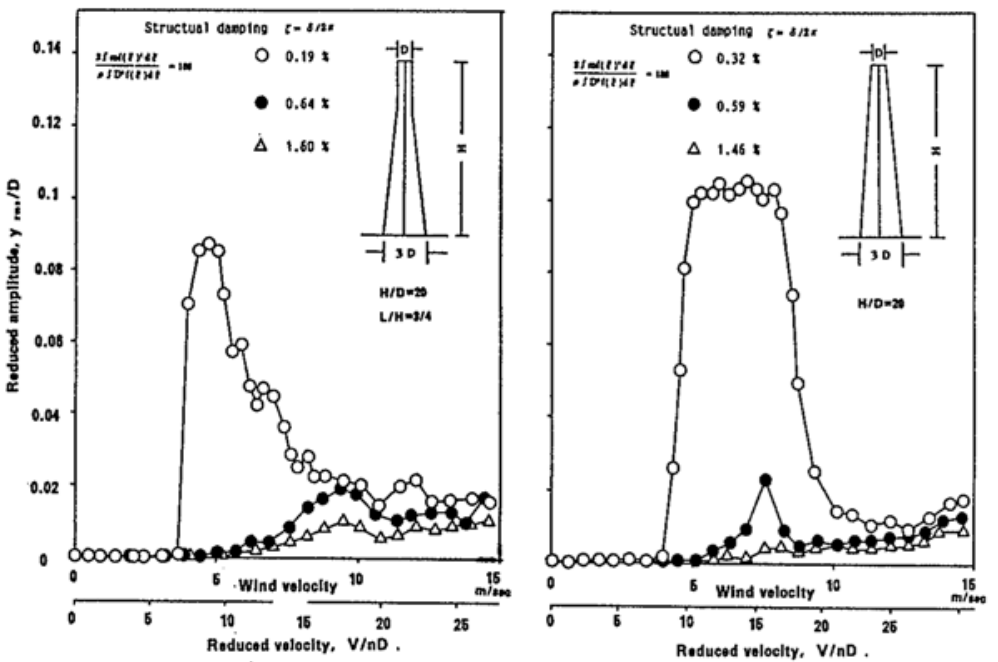

Fig.2 Across wind response of tapered cylinders in smooth flow の位置までテーパーのついた円柱（模型D）では換算 風速 7 付近, 全テーパー円柱では換算風速 8 と増大す る。

渦励振が生じる風速の範囲はテーパー部分が大きく なるにつれて拡大し，全テーパー円柱においては，換 算風速 8 から換算風速19まで極めて広い風速域で渦励 振が生じる。また，テーパー部分が $1 / 2$ までは換算風 速 5 付近から発振する渦励振のほかに, 換算風速15 16付近で高次の渦励振と見られる振幅が小さい共振振 動が生じる。

換算風速 5 から生じる渦励振は, 減衰定数を0.6 $0.8 \%$ \%すると, テーパーのある無しにかかわらず収 まる。しかし, 換算風速15付近の共振振動は振幅は小

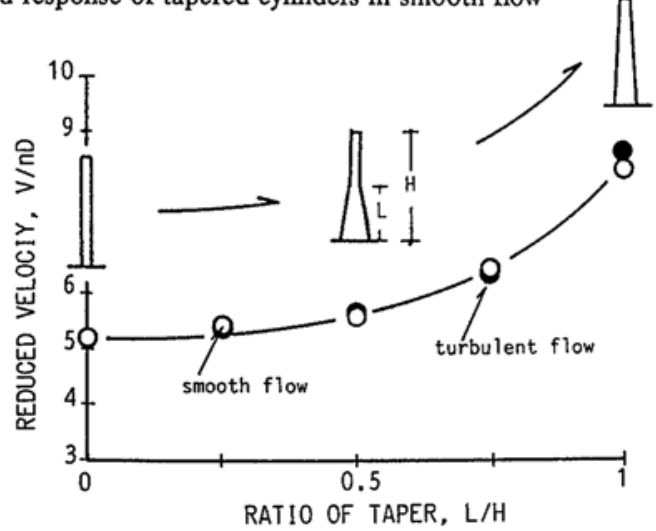

Fig.3 Onset velocity of vortex induced vibration 

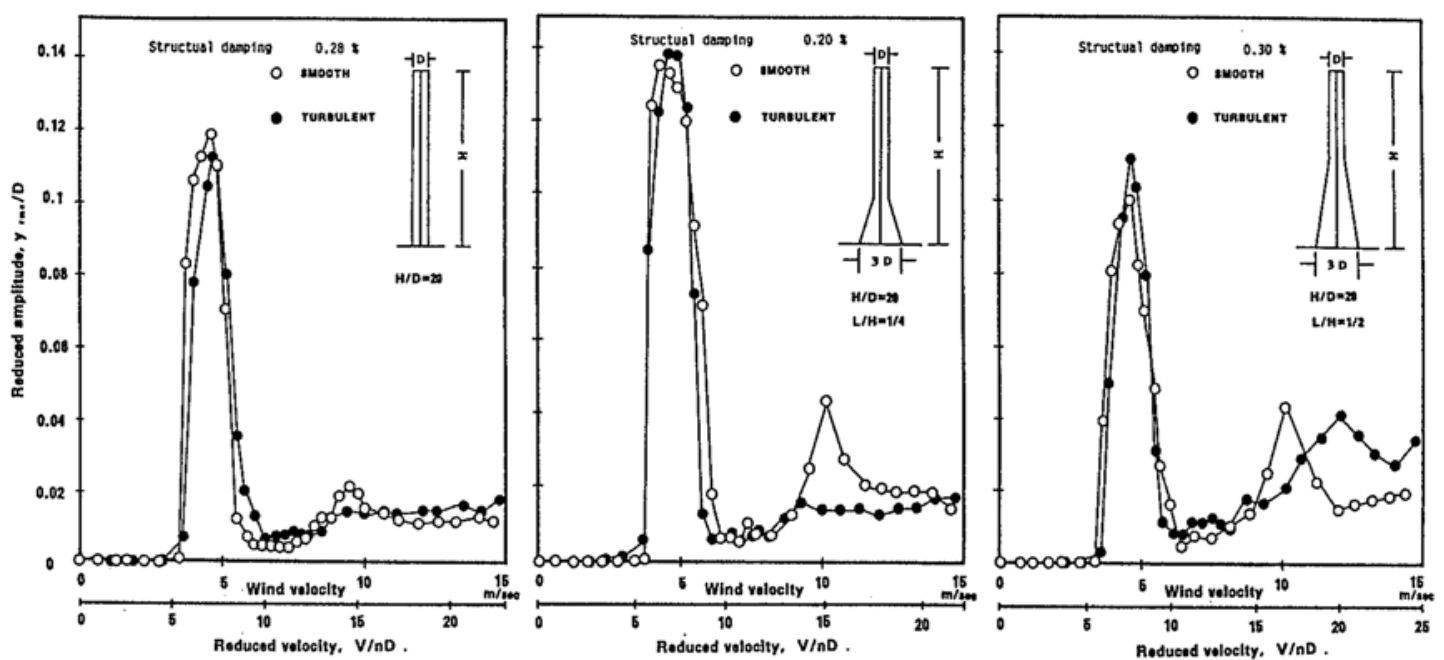

さくなるものの, 共振現象自体 は相変わらず起こり続ける。隇 衰定数が 2 パーセント近くにな ると, どの風速においても共振 現象は認められなくなる。

3. 2 乱流境界層流中での 風直角方向振動

Fig. 4 は乱流境界首流中での テーパーつき円柱の風直角方向 の応答性状を, 減衰定数 $0.3 \%$ 程度の場合について, 一様流中 と比較して示したものである。 テーパー部分が $1 / 2$ までは, 気 流の性状の違いによって応答性 状はあまり大きな影響を受けな いが， $3 / 4$ テーパー円柱及び全 テーパー円柱では, 乱流境界層
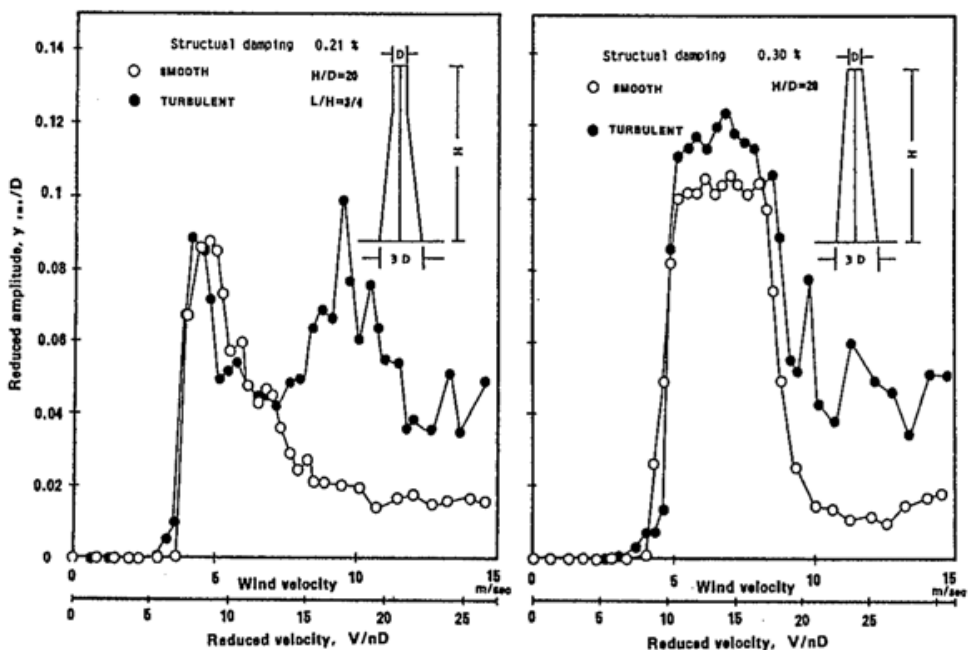

Fig. 4 Across wind response of tapered cylinders in smooth and turbulent flows
流中の方が，高風速域において振動振幅が大きくなる。 特に，3/4 テーパー円柱においては換算風速18近傍の 広範囲な風速域において, 振幅の大きな振動が観察さ れた。なおテーパー部分が $1 / 2$ 以内の場合には，乱流 境界層流中の場合，一様流中で観察された換算風速15 〜16付近の共振現象は認められなかった。なお，Fig. 3 に示したように, 乱流中における渦励振の発振風速 は，一样流中とほとんど変わらなかった。

\section{3 浻励振中のパワースペクトル密度の変化}

Fig. 5 は一様流中におけるテーパー無し及び $1 / 2$ ， 全テーパーつき円柱の風向直角方向振動のパワースペ クトルを示したものである。渦励振が始まる風速より
も風速が小さい場合には, パワースペクトルには3つ のピークが認められる。最も高周波数域にあるピーク は, 円柱の固有振動に起因するものであり, 低周波数

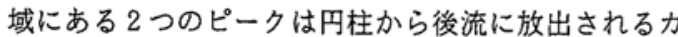
ルマン渦に起因するものであると考えられる。これら 2 つのピークに対応する換算振動数 nD/Uはそれぞれ0. 063 と0.16であり, その比は約 2.5 となっている。風 速が増大するにつれ，カルマン渦に起因するピークは 高周波数側へと移動する。やがて換算風速 5 付近にお いて渦励振が生じ振幅が急速に增大し始めるが，かな り振幅が大きくなっても高周波数側のスペクトルピー クは円柱の固有振動数に一致することはない。即ち力 ルマン渦放出が円柱の振動にロックされる状態に至る 

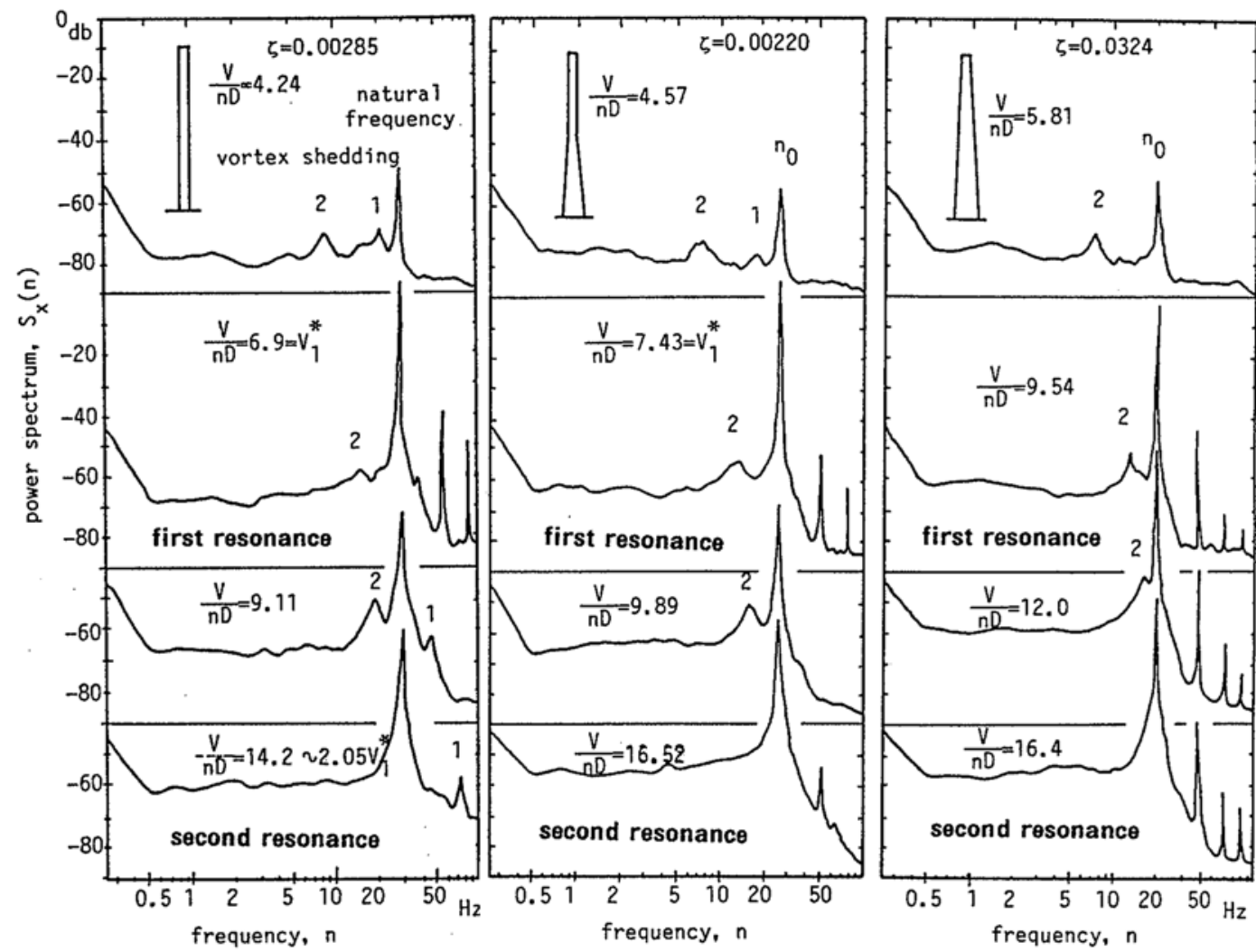

Fig.5 Power spectra of across wind responses of parallel and tapered cylinders in smooth flow

ことはない。振幅がさらに増大すると，カルマン渦に よる高周波数側のピークは円柱の固有振動数と一致し ロックイン状態にいたる。ロックイン状態では, 低周 波数側のピークの位置も変わらず，ほぼ円柱の固有振 動数の半分の周波数になる。さらに風速が増大し渦励 振が収まるにつれ，低周波数側のピークが再び風速の 增大とともに高周波数側へと移動する。このピークが 円柱の固有振動数と一致する時, 第 2 の渦励振が生じ る。このように, 高周波数側の第 2 の渦励振を生じさ せる周期的な変動風力は, 振幅が非常に小さい時にす でに存在し, その周波数は通常のカルマン渦の周波数 の1/2.5 である。

\section{4. 結論}

一様流中及び乱流境界層流中において，テーパーつ き円柱の渦励振に関する風洞実験を行い, その性状に 及ぼすテーパーの度合いの影響, 減衰の影響, 気流性 状の连いの影很を検討した。その結果以下の事実が明 らかとなった。

(1) 減衰定数が0. 3 \%程度の場合, テーパーつき円柱 はどのような場合においても，渦励振が生じる。
（2）テーパー部分が大きくなる程，渦励振が生じる風 速は高風速域へと移動し, また振動の生じる風速範 囲が大きくなる。即ち, より高風速域においてより 広範囲な風速で渦励振が生じる。

(3) 一様中よりも乱流境界層中の方か， 円柱は大きく 振動する。特に，3/4 テーパー円柱および全テー パー円柱では, 共振風速以上の高風速域における振 動が激しくなる。

(4) 減衰定数が0.6 0.8\%程度になると, 渦励振は ほとんど生じない。したがって，この種の權造物の 渦励振の制止には, TMD などの付加的な減衰装置の 設置によって構造隇衰を增加させることが極めて有 効である。

なお，本研究は俶日本鋼管の援助のもとに行われた ものである。

\section{参考文献}

1. L.R.Wotton and C.Scruton:Aerodynamic stability, The modern design of wind-sensitive structures,1971,pp 65-81. 